Does School Composition Matter More for Lower-SES Students?

A Cross-National Examination of School Socioeconomic Composition, Individual Socioeconomic Status, and Standardized Test Scores

Steven Cumberworth

Liaoning Province Shiyan High School

scumberw@gmail.com

Erin Cumberworth

Center on Poverty and Inequality

Stanford University

ecumberw@stanford.edu 


\title{
Does School Composition Matter More for Lower-SES Students? \\ A Cross-National Examination of School Socioeconomic Composition, Individual Socioeconomic Status, and Standardized Test Scores
}

\begin{abstract}
This paper investigates whether school socioeconomic composition has a stronger association with standardized test scores among lower-socioeconomic status (lower-SES) students than it does among higher-SES students. School socioeconomic composition, measured here as average SES, has repeatedly been demonstrated to have a strong influence on a variety of student outcomes, but there has been little systematic examination of whether this association is stronger for more disadvantaged students. Such a finding would be consistent with evidence from related research areas suggesting that the learning outcomes of disadvantaged students are particularly sensitive to schools and school characteristics. We use data from a large, cross-national studythe Programme for International Student Assessment (PISA) - to examine patterns across a wide variety of economic, demographic, and cultural contexts. Contrary to expectation, we find no general pattern of school socioeconomic composition being more strongly associated with test scores among lower-SES students; if anything, the relationship appears to be slightly weaker among lower-SES students.
\end{abstract}




\section{Does School Composition Matter More for Lower-SES Students? \\ A Cross-National Examination of School Socioeconomic Composition, Individual Socioeconomic Status, and Standardized Test Scores}

Perhaps one of the most consistent findings in education research is the presence of a strong correlation between a student's academic achievement and his or her family background. Students from more advantaged families - for instance, those with higher family incomes or with more educated parents - tend to do better in school. They tend to receive better grades and higher scores on standardized tests, and they are more likely to graduate from high school, to enroll in college, to attend more selective colleges, and to graduate from college. The strength of the association may vary, but this pattern has been found in virtually every setting and among virtually every population in which it has been investigated (OECD 2004; Sirin 2005).

There is also a substantial body of evidence suggesting that above and beyond the impact of individual socioeconomic status (SES) on academic outcomes, there is an additional impact from the socioeconomic composition of the school a student attends. Among students with similar family backgrounds, those who attend schools with higher-SES peers tend to have better outcomes than those who attend schools with lower-SES peers. In fact, the general consensus has been that a school's socioeconomic composition is more important in predicting student outcomes than any other school characteristic, including material resources and teacher credentials. This point was made most famously by James Coleman and his collaborators in a 1960s report Equality of Educational Opportunity, usually referred to simply as the "Coleman Report" (Coleman et al. 1966). Coleman was commissioned to conduct a study of racial segregation in U.S. schools, and after examining data from hundreds of schools across the country, he concluded that, (a) the composition of a school's student body is more strongly 
related to individual achievement than any other school factor he and his colleagues examined, and (b) that as a result of this, the only way to address educational inequality between white and black children in the U.S. would be to desegregate schools. The report had a massive impact on both education policy and on education research, and in its wake came a multitude of studies attempting to replicate, refine, and expand on its findings. And while there has been some disagreement about the size of school composition effects (e.g., see Marks 2015), the bulk of the evidence continues to suggest that it does matter, at least for some students in some contexts (Kahlenberg 2001; Rumberger and Palardy 2005; van Ewjk and Sleegers 2010).

In this study, we take this last point as our starting point — that school socioeconomic composition has an impact on outcomes for individual students, at least for some students in some contexts - and we test the hypothesis that students from more disadvantaged backgrounds are more sensitive to school composition than are students from more advantaged backgrounds. Such a finding would be consistent with a growing body of evidence from research in related areas. For instance, lower-SES students appear to be more sensitive to class size in early education (American Educational Research Association 2003), to fall behind their higher-SES classmates at a faster rate during summer breaks than during the school year (Alexander, Entwisle, and Olson 2007), and to benefit more than other students from attending highlyselective colleges and universities (Dale and Krueger 2011). Taken together, these types of findings suggest that schools serve as "equalizers" that promote intergenerational mobility and equality of opportunity by providing to lower-SES students some of the academic resources that more advantaged students can more easily obtain in non-school settings.

To test our hypothesis, we use a large, cross-national dataset, the Programme for International Student Assessment (PISA), which includes measures of achievement in science, 
reading, and math among 15 -year old students in over sixty countries. The study has some shortcomings, and we discuss these at length below, but it also has some important advantages for taking on this question. The data are collected through a major international effort, with measures that are carefully tested and developed to maximize both the validity of the measures and their consistency across countries. The large numbers of schools and students within each country make it possible to tease out complex relationships between individual and school characteristics, and the large number of countries that participate in the PISA allow us to make more general claims than previous studies on this topic have attempted.

Our results are somewhat surprising. Contrary to expectation, we find no general pattern of school socioeconomic composition having a stronger association with test scores among lower-SES students than among higher-SES students. A small number of countries do have this pattern of scores, but in the vast majority of countries, there is either no difference between lower-SES and higher-SES students, or the association is stronger for higher-SES students. When data for all countries is combined in a single model, the association between school composition and test scores is significantly smaller for lower-SES students than for other students. In our conclusion, we discuss possible implications of this finding for policy and more broadly for our understanding of how schools contribute to social reproduction.

\section{Review of Existing Research}

\section{Evidence from Studies in Related Areas}

The hypothesis that school composition matters more for lower-SES students is consistent with a growing body of research suggesting that disadvantaged students are more sensitive in general to schooling and to various characteristics of schools than are more 
advantaged students. We highlight three specific research areas where this is the case: in the rate of "losing ground" during summer breaks, in the effect of class size on achievement in early elementary, and in the effect of attending highly-selective colleges or universities.

A substantial body of research documents a "summer learning gap" among elementary and high-school children in the U.S. This literature has found that during summer breaks when school is not in session, lower-SES students fall behind their higher-SES classmates at a faster rate than they do during the school year. When students are tested in the spring before school lets out, and then again in the fall when school is back in session, the declines in test scores are consistently larger for lower-SES students. This pattern was first documented in the 1970s by Barbara Heyns, in a study of public middle school students in Atlanta (Heyns 1978), and it has been replicated in a variety of other settings (Alexander, Entwisle, and Olson 2007; Burkham et al. 2004; Downey, von Hippel, and Broh 2004; Entwisle and Alexander 1992; Heyns 1978; Heyns 1987; see Cooper et al. 1996 for a review).

Lower-SES kids also seem to be more sensitive to the impact of small class sizes. This finding has not been ubiquitous (e.g., Nye, Hedges, and Konstantopoulos 2000), but most evidence suggests that smaller classes in the early years of elementary school have a significant impact on student learning, and that this impact is particularly strong for the most disadvantaged students (American Educational Research Association 2003; Grissmer et al. 2000; Hanushek, Kain, and Rivkin 1998; Summers and Wolfe 1977).

Finally, there is also evidence suggesting that for college students in the U.S., the benefit of attending a highly-selective college or university is strongest for the most disadvantaged students (Dale and Krueger 2011). It is notoriously difficult to study the impact of college selectivity on achievement, because colleges admit students using more sophisticated indicators 
of talent and ability than are typically available to researchers. However, Dale and Krueger used an innovative design in which they controlled for the selectivity of the schools to which students applied. In doing so, they found that while attending more selective schools had little impact on post-college earnings for all students combined, it did have a big impact for certain subgroups, including students from lower-SES backgrounds.

Taken together, these types of findings suggest a general pattern where lower-SES students appear to gain the most from increased access to schooling and to better schooling. Whatever it is that schools provide that promotes student learning and achievement, it may be that higher-SES students are more likely to be able to access those resources outside of schoolfrom their parents or extended families, from neighborhood- or church-based social networks, or from other non-school social settings. Thus, differences in the presence or quality of schools will tend to have a stronger impact on outcomes for lower-SES students.

\section{Direct Evidence on School Socioeconomic Composition}

Only a small number of studies have directly examined whether lower-SES students are also more sensitive to the impact of school socioeconomic composition. For the most part, the few studies that do exist do not provide much evidence in support of this hypothesis.

In a series of papers looking mainly at data for Australia, Perry and McConney (2010a, 2010b; McConney and Perry 2010) find that the relationship between school composition and test scores appears to be about the same in magnitude for lower- and higher-SES students. They find a similar pattern among students in Canada (Perry and McConney 2013). Using data from the United States, Rumberger and Palardy (2005a) also find that school composition has just as much impact for high-SES students as it does for low-SES students; Willms (1986) found the 
same in a study of students in Scotland. Furthermore, some studies have found that more advantaged students actually derive more benefit from attending the higher-SES composition schools, at least among students in the U.S. Palardy (2008) found that students from high-SES families benefit more from attending schools with a high average SES than do students from low-SES families; Wells (2010) found similar results between immigrant and non-immigrant children.

Thus, the literature as a whole does not provide a clear answer on whether composition effects are strongest for lower-SES students. A substantial amount of evidence points to the conclusion that schools matter more for more disadvantaged students, and would suggest that this is probably the case for school socioeconomic composition as well. This would be consistent with the image of schools as equalizers that promote equality of opportunity. However, the small amount of direct evidence available suggests that this may not be the case for the school socioeconomic composition.

\section{The Current Study}

Our aim in the current study is to examine the relationship between standardized test scores, school socioeconomic composition, and the family SES of individual students. We assess whether there is a general, cross-national pattern of lower-SES students benefitting more from attending high-SES schools than other students. By using a cross-national dataset, we are able to look for general patterns that transcend the specifics of any particular country, each with its own demographic, economic, and social characteristics. The dataset also has high-quality measurements of student learning and family SES that have been subject to considerable scrutiny 
and testing, and that have been developed with attention to maximizing consistency across countries.

The study design is not without flaws, however, and there are two shortcomings in particular to which we must give careful attention. First, the PISA is a cross-sectional survey with no measures of student ability prior to entering the current school; this severely limits our ability to draw conclusions about the impact of attending a particular type of school. Second, because the only outcome we examine is standardized test scores, we undoubtedly miss some of the important ways in which school composition can impact longer-term outcomes such as high school graduation and college enrollment. We address each of these shortcomings in greater detail below.

\section{Measuring School Effects without Random Assignment}

Without students being randomly assigned to schools, we cannot measure the true effect of attending a particular type of school. This is a problem that has plagued much of the literature on school effects, including the Coleman Report itself. Furthermore, we cannot use the most common strategy to deal with potential selection bias, which is to control for student ability prior to entering the current school, as no measure of prior ability is available in the PISA dataset. Marks (2015) has shown that controlling for prior achievement has a considerable impact on estimates of school effects—what appears to be a strong correlation between school socioeconomic composition and test scores gets much smaller in magnitude when controlling for individual- and school-level prior ability.

However, our interest is not in measuring the size of school effects per se. Our question is whether those effects matter more for lower-SES students than for higher-SES students. For this, 
our key assumption is that to whatever degree our estimates are upwardly biased, the degree and nature of the bias is more or less the same for high-SES and low-SES students. Furthermore, since we are looking at patterns across a large number and variety of countries, any alternative explanation for the patterns we find would have to be a general explanation that is not specific to any particular national context, but holds true across a wide variety of national contexts.

In fact, we argue that if the degree of bias in our estimates is not the same for both highSES and low-SES students, it is likely higher for lower-SES students. This is because the sorting of students into schools probably depends more on pre-existing ability for lower-SES students. High-SES students are more likely to attend high-SES schools for reasons not directly related to ability, such as living in high-SES neighborhoods or having parents with the financial resources to pay higher tuition. Lower-SES kids, on the other hand, would be more likely to be selected into high-SES schools on the basis of ability, for instance through magnet schools or merit-based scholarships. The opposite process is also, of course, plausible: the high-SES students who end up in low-SES schools may in part end up there because of low academic abilities, but this is probably relatively less common. For these reasons, we think it is likely that our results are biased in favor of our hypothesis - that lower-SES students might appear to be more sensitive to school composition because they are in fact more likely to be sorted into schools on the basis of pre-existing ability. In the early stages of the designing the study, when we expected the results to be consistent with our hypothesis, we worried about how to deal with this potential source of bias. It quickly became clear, though (as will be demonstrated below), that the PISA data show the opposite pattern. This makes our results all the more striking - the mis-measurement of school composition effects likely biases the results in the opposite direction of what we find and report. 


\section{Test Scores versus Other Student Outcomes}

A second aspect of the current study that limits the scope of the conclusions we can draw from it is that the only outcome we examine is standardized test scores. Certainly, test scores are an important outcome in and of themselves. The types of information included in the PISA are specifically designed to reflect the basic knowledge needed to be a functional and well-informed citizen, and the ability of schools to transfer this knowledge to students is an important end in its own right. Beyond that, the more general ability to successfully take this type of exam-to read and understand the questions, to follow instructions, to engage in critical thinking, and to be motivated to take the assessment seriously and try to do well-may reflect the ability to navigate other types of institutional settings successfully as well. Test scores also serve as important predictors of later outcomes, such as graduating from high school, entering college, attending a more prestigious college, completing a college degree, and ultimately performing well in the labor market.

Nonetheless, for longer-term outcomes, it would of course be optimal to have direct measures. Test scores may be good predictors of later achievements, but certainly are not perfect. Furthermore, some of the benefit of attending a higher-SES school might be that it gives students the tools they need to make the most of their test scores, whatever those scores may be. For example, high-SES schools might provide their students better information about how and when to apply to colleges, or they may offer more personalized information about the best choices for each student. They might also provide "cultural capital" that can help students impress college admissions officers, interviewers, or employers, by writing compelling admission essays or knowing how to present themselves more successfully in interviews. Indeed, there is some 
evidence that school composition does have a bigger impact on longer-term outcomes than it does on standardized test scores (Rumberger and Palardy 2005b).

Unfortunately, there are no measures of long-term student outcomes in the PISA dataset, so we-like many studies in this area—can only look at test scores. This means we can only examine part of the process through which school composition affects student outcomes. It is nonetheless an important part of the process, though. As noted above, test scores are important in and of themselves as indicators of valuable knowledge and skills, and they also serve as a strong, even if flawed, proxy for students' likelihood of success in other areas.

\section{Data and Methods}

We use data from the Programme for International Student Assessment (PISA), a crossnational survey of 15-year old students that has been administered by the Organization for Economic Cooperation and Development (OECD) every three years since 2000. The PISA data have been widely used and are a common source for cross-national comparisons of student test scores. We use data from PISA 2015, in which a total of 519,334 students in 17,911 schools across 69 countries participated. (Some of these countries and students are excluded from our analysis due to lack of sufficient data—we describe the construction of our analytic samples in more detail below.)

The PISA has a nested structure. Within each participating country, a random sample of schools is selected, and then a random sample of students is selected within each school. The survey includes assessments of math, science, and reading skills that take most students about two hours to complete. It also collects demographic information such as family wealth and parental education. A separate questionnaire is completed by the principal of each participating 
school to provide information about the school's resources, its teachers and staff, and various other school-level characteristics. The variables used in our analysis are summarized in Table 1. [Table 1 about here]

\section{Standardized Test Scores}

The outcome variable used in all of our analyses are test scores from the PISA science, math, and reading assessments. We estimate models using scores from each of the three subjects, but we focus primarily on science scores. Each PISA cycle focuses on one subject, and in 2015 the focus was science. The science assessment was longer and included more questions than the reading and math assessments, making the science score the most reliable indicator for that survey year. The science assessment was designed to cover a wide range of content, so each student was randomly assigned a test form with around thirty items representing only a fraction of the total items. The OECD then generated an estimate of overall science proficiency based on the responses to the randomly-assigned items. Most scores were between 100 and 800 points, with an average of 465 points. A score of 410 points is considered the baseline level of proficiency required to be a critical and informed citizen; students with scores above 633 points are considered top performers (OECD 2016).

\section{Student Socioeconomic Status (SES)}

To measure individual SES, we use the PISA index of economic, social and cultural status (ESCS). This variable is derived by the OECD from a principal components analysis of three variables: highest parental level of education, highest parental occupational status score, and a measure of home possessions (described below). The ESCS index is scaled to have an 
average of zero and a standard deviation of one across equally-weighted OECD countries_-for the full sample, the mean is a bit lower and the standard deviation a bit larger. Some of our models use the continuous version of the index, but in our main analysis we divide students into SES quintiles within countries.

One of the three components of the ESCS index is a measure of home possessions, which is included as a proxy for family wealth. The measure is computed from a series of questions on the student survey about whether their homes contain certain items (and in some cases, how many of the items). Most of the items were the same across countries and included things such as a room of their own, a computer, and an internet connection; and the number of televisions, cars, and bathrooms. Three questions varied by country to reflect appropriate measures of family wealth in each country. For example, students in the U.S. were asked if their homes had a guest room, a high-speed internet connection, or a musical instrument; students in China were asked if their home had a vacuum cleaner, a digital camera, or a juicer. Based on these questions, the OECD constructed a summary measure of home possessions which was then used (along with parental education and occupational status) to generate the ESCS index.

\section{School Socioeconomic Composition}

We measure school socioeconomic composition as average student SES. This variable is not included in the PISA dataset; we estimate it ourselves using the average ESCS index (described above) for the sampled students in each school. Among the 17,637 schools in our main analytic sample, the vast majority had a sufficient number of sampled students to generate reasonably reliable estimates of average school SES; the median school had 30 sampled students. However, about 5.6 percent of schools had fewer than ten sampled students, and about 4.5 
percent had fewer than five sampled students. We estimated all models both with and without these small-sample schools, and we found that excluding them did not change our results in any meaningful way. So, rather than choose an arbitrary cut-off point, we present results with all schools included.

In our main models, we use a continuous version of the school socioeconomic composition measure. We standardize the variable within countries, using the individual-level mean and standard deviation. This means that the values of the standardized variable represent the distance between the average SES of the school and the individual-level average SES of the country, measured in individual-level standard deviations. We do this because countries have different levels of economic segregation between schools, and we don't want these differences to influence our results. A score of (for example) 1.5 represents the same thing in every countrythat the average SES of the students attending a school is about 1.5 standard deviations above the national average SES - regardless of whether this is a typical or an extreme case for schools in that country.

In some analyses, we use alternative measures of school composition. In some, we divide schools into quintiles within countries. We also use a dummy variable for "non-poor schools," which is equal to one if fewer than 40 percent of students are in the country's bottom SES quintile. (While a dummy for "poor schools" might be more natural, we use a "non-poor" dummy instead so that positive regression coefficients will have the same general interpretation as for the other school composition measures.) 


\section{School-Level Control Variables}

Teacher credentials. To measure teacher credentials, we use the percentage of teachers with a Master's degree equivalent or higher, which is calculated using information from the principal questionnaire. Principals were asked to report the total number of teachers in the school, the number with a Bachelor's degree equivalent, the number with a Master's degree equivalent, and the number with a doctoral degree equivalent. They were instructed to include teachers only in the category of the highest degree they had earned. However, a cursory examination of responses makes it clear that many principals did not follow these instructions. When the counts are converted to percentages, the sum of the three percentages is greater than 100 in more than a quarter of schools. It appears likely that many principals included teachers at every level of credentials they had achieved. To deal with these reporting errors, we use the following coding scheme: if the sum of reported percentages is equal to or less than one, we assume the principal followed the instructions, and we add together the percentage of teachers with Master's degree equivalents and the percentage with doctoral degree equivalents. About 70 percent of schools fall into this category. If the sum of the reported percentages is greater than one and the percentages descend across categories (that is, the percentage with a Master's degree is lower than the percentage with a doctoral degree, and the percentage with a Bachelor's is lower than the percentage with a Master's), then we assume the principal included teachers at every degree level they had achieved and thus use the percentage with Master's degrees alone (without adding to it the percentage with doctoral degrees). About 25 percent of schools fall in this category. If the sum of percentages is greater than one and the percentages don't descend across categories, we code the variable as missing. This is necessary for about 5 percent of 
schools. The final variable has a natural range of 0 to 1 ; in our models, it is mean-centered across schools, within countries.

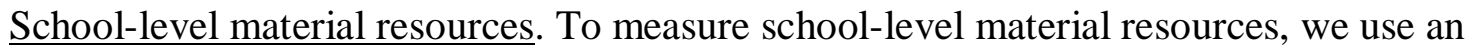
index of science-specific resources. Since science was the main focus of the 2015 assessment, the principals' survey included a series of eight yes/no questions about whether the school's science department was well-funded, well-equipped, and well-staffed. The index is simply the sum of the number of "yes" responses. It has a natural range from 0 to 8 and an overall mean of 4.5; for our models, we mean-center it across schools within countries.

Disruptive behavior. We use two index measures included in the PISA dataset to measure principals' perceptions of disruptive student and teacher behavior. Principals were asked to report the degree to which each of a list of specific behaviors hindered learning in their schools. For each item, the principal chose from four response categories: "not at all", "very little," "to some extent," and "a lot." For student behavior, they were asked about truancy, skipping class, lacking respect for teachers, using alcohol or illegal drugs, or intimidating or bullying other students. For teacher behavior, they were asked about not meeting individual students' needs, absenteeism, resisting change, being too strict with students, and not being well-prepared for classes. Higher values indicate greater incidence of disruptive behavior. In our models, both variables are mean-centered within countries.

\section{Country-Level Control Variables}

We control for four country-level variables: OECD membership, Gross Domestic Product (GDP) per capita, Gini coefficient, and federal education expenditures as a percentage of GDP. OECD membership is a dummy variable equal to one for OECD members and zero otherwise. 
The other three variables are from the World Bank. For GDP per capita, we use data for 2015 for all countries. For the Gini coefficient, we use data for 2015 if it is available, but if data is not available for 2015, we use data for the most recently-available year, going back as far as 2008 . For federal education expenditures, we use per-student federal expenditures on secondary education as a percentage of GDP per capita. We use data for 2013 if available (since data for more recent years is available for only a small number of countries). When data for 2013 is not available, we use data for the closest year possible, in the following order: 2014, 2012, 2011, and so on, back as far as 2006. Table 1 reports the natural ranges for these variables, but in our models all but OECD membership are standardized across countries.

\section{Sample Construction}

As noted above, a total of 519,334 students participated in the 2015 PISA. However, not all of these students are included in all parts of our analysis due to missing data. To help readers make sense of differences in sample sizes across different parts of the analysis, Table 2 describes how the various samples were constructed and clarifies the sources of missing data. Note that in some cases, the sample size drops considerably due to entire countries being excluded from the analysis. These country-level exclusions are unfortunate in that they reduce the number of countries on which we can base our conclusions, but since the original sample of countries was not selected using probability sampling methods, they do not introduce any new source of statistical bias.

[Table 2 about here]

Sample 0 in Table 2 indicates that the full PISA 2015 sample included 519,334 students in 69 countries. However, we must exclude from all parts of our analysis cases for which we 
have no measures of individual SES or for which we cannot calculate school-level average SES. This means we exclude all students from Albania, for which student SES is not reported. We also exclude data for Puerto Rico, Massachusetts, and North Carolina due to lack of school-level information needed to calculate average SES. (Puerto Rico, Massachusetts, and North Carolina participated in the survey as separate entities apart from the rest of the United States.) After excluding these four countries and states, we are left with a sample of 509,182 students in 68 countries and regions. Within this sample (Sample 1), another two percent of cases are missing the student SES variable, and these are excluded through casewise deletion. This leaves 498,493 students nested in 17,637 schools across 68 countries and regions (Sample 2).

We consider Sample 2 our main analytic sample, but in some parts of our analysis the sample is reduced further due to missing country-level or school-level information. A total of eighteen countries and regions are missing one or more of the country-level variables (GDP, Gini coefficient, or education spending): Algeria, China, Chinese Taipei, Croatia, Greece, Hong Kong, Kosovo, Macao, Macedonia, Malta, Montenegro, New Zealand, Qatar, Russia, Singapore, Trinidad and Tobago, the United Arab Emirates, and Vietnam. Excluding these countries leaves a total sample of 383,171 students in 50 countries (Sample 3). Within Sample 3, there are another 3,550 schools with insufficient data from the principal questionnaire to be included in analyses with school-level control variables. Dropping these schools leaves a sample of 290,332 students in 50 countries. We call this Sample 4. (Note that if models are estimated with schoollevel control variables but no country-level control variables, it is possible to use a much larger sample because many of the students from countries with missing country-level data could be included. We did estimate such models, but results are not shown or discussed because the overall pattern of results do not differ in any meaningful way from the results presented.) 


\section{Method of Analysis}

Our primary method of analysis is hierarchical linear modeling (HLM). The PISA dataset naturally lends itself to this method because students are nested within schools, and schools within countries. In our main analysis, we estimate three-level models in which the level-1 units are students, the level-2 units are schools, and the level-3 units are countries. The outcome variable in most models is science score; in some supplemental models we alternatively use math and reading scores. To better assess variation across countries, we also estimate two-level models separately for each country. These models include individual SES, school socioeconomic composition, and an interaction between the two.

\section{Results}

\section{Descriptive Results}

We start by showing data for a single country, France, in order to make conceptually clear what types of relationships we are investigating, and what terminology we use. Table 3 shows average science scores for France, by individual SES quintile, by school socioeconomic quintile, and for each cell of a 5x5 cross-tabulation of the two. A total of 6,108 French students, drawn from 252 schools, participated in the survey. A small number of students $(\mathrm{N}=167$, or 2.7 percent of the total French sample) were missing information about their family SES, and are therefore not included in the table, leaving 5,941 students.

Overall, the average science score among French students was 498 points. The first column of Table 3 shows that, predictably, the average score increases across student SES quintiles, from 436 points for students in the bottom quintile to 563 points for those in the top quintile. The top row shows a similar pattern across school quintiles. Students in bottom-quintile 
schools have an average test score of 400 points, and those in top-quintile schools have an average of 567 points. The difference of 167 points between students in top-quintile schools and those in bottom-quintile schools we refer to as a "composition effect." The cross-tabulation of individual SES quintiles by school quintiles gives a sense of how the composition effect varies across individual SES quintiles. Among students in the bottom quintile, there is a gap of 123 points between students in top-quintile schools and those in bottom-quintile schools; among students in the top SES quintile, there is an even larger gap of 169 points. This pattern is contrary to our hypothesis that composition matters more for lower-SES students, but as will be demonstrated, it is typical of many countries in the sample.

[Table 3 about here]

Table 4 expands the descriptive analysis to include all countries for which we have sufficient data. There is not space to show the full cross-tabulation of individual SES by school composition for each country, so we show only the numbers corresponding to the final column of Table 3 - the size of the composition effect for students in each individual SES quintile. The last column of Table 4 then shows the difference between the composition effect for top-quintile students and the composition effect for bottom-quintile students. Positive numbers mean that the composition effect is larger among higher-SES students; negative numbers mean it is larger among lower-SES students. A cursory glance at the table suggests there is little evidence here in support of our hypothesis that school composition matters more for lower-SES students, and that if anything, the opposite appears to be true. For 46 out of the 61 countries for which we can compute these estimates, the raw composition effect is larger for higher-SES students than it is for lower-SES students.

[Table 4 about here] 
Figure 1 shows graphs of average test scores by individual SES quintile and school composition quintile, for nine selected countries. (Note that these graphs only show data for students in the bottom, middle, and top quintiles — the second and fourth quintiles are omitted for clarity.) These nine countries were chosen to show the range of variation across countries. We show graphs for the three countries at the top, the three countries at the bottom, and the three countries in the middle of the list in Table 4, which is ordered by the size of the difference between top-quintile and bottom-quintile students. In the top row are Austria, Qatar, and Israel, the three countries with the biggest positive differences between the highest and lowest quintiles. In these countries, test scores appear to be more strongly associated with school composition among higher-SES students than among lower-SES students. In the bottom row are the three countries at the other extreme-Singapore, Switzerland, and Czech Republic — which are among the small number of countries for which the association appears to be stronger for lower-SES students. Mexico, Lithuania, and Bulgaria fall in the middle, with little apparent difference either way between high-SES and low-SES students.

[Figure 1 about here]

\section{Hierarchical Linear Models}

Next we use HLM to test our hypothesis more systematically. Table 5 presents estimates from three-level models in which student science score is the outcome variable. Model 1 is a baseline model that includes only two independent variables, student SES quintile and the standardized school composition variable. As expected, test scores increase significantly across student SES quintiles_overall, students in the second SES quintile (within countries) have predicted scores 11 points higher than students in the bottom quintile; those in the top quintile 
have predicted scores 40 points higher. School socioeconomic composition also has a strong association with science scores. A one-unit increase in the composition variable increases the expected test score by over 50 points. (Recall that a one-unit increase corresponds to a change in average school SES equal to one standard deviation in individual-level SES, which is a fairly large increase at the school level.)

[Table 5 about here]

In Model 2, we add interaction terms between individual SES and school composition, which is the main focus of this study. Note that we estimate Model 2 using two different samples, first using the same sample used in Model 1, and then again using the smaller sample used to estimate Models 3 and 4. In interpreting the results, we focus on the first set of estimates; the second set is only presented to allow more direct comparison with the last two models. As can be seen, the interaction terms between school composition and individual SES are all positive and statistically significant, meaning that the school composition coefficient becomes significantly larger as student SES increases. For students in the bottom income quintile, increasing school composition by one unit increases the expected test score by about 49 points; for students in the top quintile, it increases the expected test score by about 58 points. This pattern is consistent with the results shown in Table 4 and Figure 1, and is opposite to what we hypothesized. Rather than low-SES students' test scores being more strongly associated with peer SES, the association is stronger among higher-SES students. Note also that the difference appears to be mainly between students in the lowest quintile versus those in the top three; the interaction terms for the top three quintiles are all very similar in size.

To test the robustness of these associations, we add control variables at the country level (Model 3) and the school level (Model 4). Since doing so necessitates that countries and schools 
with missing data on the school- and country-level variables be excluded from the sample, we first re-estimate Model 2 using the smaller sample so that it can be more directly compared to the subsequent models. Fortunately, there are no major differences in the model parameters for the two different samples. The point estimates are slightly different, as would be expected, but the overall patterns are the same.

Model 3 adds the four country-level variables. Some of these variables have a significant impact on test scores-OECD membership, GDP per capita, and levels of federal education spending are all associated with higher test scores. But the more relevant result for our purposes is that the estimates for the interaction terms between student SES and school composition remain virtually unchanged with the addition of the country control variables. In Model 4, we add the school-level variables: teacher credentials, science resources, and disruptive student or teacher behavior. Again each of these variables has a significant impact on predicted test scores. Note also that the coefficient for the school composition variable becomes slightly smaller in this model-dropping from 42.6 points in Model 3 to 36.9 points in Model 4—suggesting that school characteristics explain some of the association between school composition and test scores. However, there is still a strong association between school composition and scores in model 4, so those factors explain some but not all of the correlation between school composition and test scores. And most importantly for our purposes, the coefficients for the interaction terms between student SES and school composition remain nearly unchanged.

\section{Alternative Model Specifications}

To further test the robustness of our findings, we re-estimate Model 2 using different outcome variables and different methods of constructing the SES and school composition 
variables. In addition to using science score as the outcome variable, we also use reading and math scores. We use two ways of measuring individual SES: the quintile measure used in Table 5 and a continuous version of the variable, mean-centered within countries. We use three ways of measuring school socioeconomic composition: the continuous version used in Table 5, a quintile measure in which schools are divided into within-country quintiles based on their average SES, and a dummy variable for non-poor schools. The results are presented in Tables 6 (science scores), 7 (reading scores), and 8 (math scores).

[Tables 6, 7, and 8 about here]

The results indicate that in all cases, patterns are similar to what is shown in Table 5: the correlation between school composition and test scores is positive and statistically significant, and this relationships is even stronger for higher-SES students than it is for lower-SES students. This pattern is the opposite of what we would expect if our hypothesis that school composition matters more for lower-SES students were correct. Of course, all eighteen versions of the model are estimated using the same sample and the same underlying data, meaning that many of the problems inherent in the PISA dataset are common to all models. Nonetheless, the robustness of results across a wide variety of models indicate that the pattern of results we find is not dependent on any particular coding decision.

\section{Variation across Countries}

Next, we examine how the results vary across countries. For each country, we estimate a two-level HLM with students as the level-1 unit and schools as the level-2 unit. The models include individual SES quintile, school socioeconomic composition, and an interaction between the two. Table 9 summarizes the results. We group countries based on the direction of the 
interaction term between individual SES and school composition, and by whether or not the interaction is statistically significant $(\mathrm{p}<.05)$. Recall that a negative interaction term indicates that the association between school composition and test scores is higher for lower-SES students; a positive interaction term indicates that the association is stronger for higher-SES students; and in countries with no significant interaction, the association is about the same for low-SES students as it is for high-SES students.

\section{[Table 9 about here]}

In total, only three countries have a significantly negative interaction between SES and school composition: Japan, Latvia, and Singapore. For these countries, the data are consistent with our hypothesis that peer effects would be larger for lower-SES students. On the other hand, in 24 countries the relationship is opposite of what we hypothesized: school composition is significantly more associated with scores among higher-SES students. In the remaining 41 countries, there is no significant interaction between the two variables. Even among the countries with no significant interaction, it is notable that 28 have an interaction term that is positive in direction and only 13 have an interaction term that is negative in direction.

In Figure 2, we show a map with countries shaded by the direction and statistical significance of the interaction between school composition and the highest individual SES quintile. Countries shaded dark blue have negative interaction terms, and those shaded dark red have positive interaction terms. Countries with light red or blue shading have statistically insignificant interaction terms. The map shows again that there are far more blue countries than red, as was apparent from Table 9, and as would be expected based on the models presented in Table 5. The map also shows no overly apparent patterning by geography. The few red countries are not clustered in any particular part of the world. 


\section{Split-Sample Models}

Finally, in Table 10, we look more carefully at whether these patterns differ in any systematic way between different types of countries. We estimate models separately for OECD countries and non-OECD countries, for rich and poor countries, for low-inequality and highinequality countries, for countries with more segregated and less segregated schools, for Asian countries, and for European countries. For all but the OECD/non-OECD and the European/Asian splits, we define "high" and "low" based on the distribution of countries in our sample; countries above the median are "high" and those below the medium are "low." For all but the European/Asian split, all countries are included in either one category or the other unless we have no data for the country on that variable (e.g., some countries are missing data for the Gini coefficient or for education expenditures). Also note that the models presented in Table 10 contain no control variables. We did estimate models with control variables included, and this drastically reduces sample sizes, but the results are substantively the same.

The results show that, by and large, the pattern we found for the entire sample is present in all twelve subsamples as well. Thus, if there are other plausible explanations for the pattern we find of school composition having the same impact on test scores for lower-SES and higher-SES students, those explanations must not be dependent on the demographic, social, or economic processes unique to any specific country or specific type of country. They must be general explanations that cross-cut the wide variety of countries for which we have data.

\section{Conclusion}

This study was designed to test the hypothesis that the learning of lower-SES students is more sensitive to school socioeconomic composition than is the learning of higher-SES students. 
While the existing literature provides no clear answer to this question, there is a good deal of evidence from studies in related areas suggesting that disadvantaged students tend to be more sensitive to the characteristics of their schools in general. We use a large, cross-national dataset - the 2015 PISA - to assess whether the same is true with regard to school composition. The large number and variety of countries that participate in the PISA, and the large sample sizes within each country, allow us to look for general tendencies and patterns that cross-cut very different national contexts.

Contrary to expectation, we find no evidence that the association between standardized test scores and school socioeconomic composition is stronger for lower-SES students than for higher-SES students. In fact, if anything the association appears to be slightly stronger for higher-SES students. This is a robust pattern that we find using a wide variety of coding strategies and model specifications. The same patterns are apparent in simple descriptive crosstabulations, in multilevel models with country and school controls, and regardless of how the key variables are coded or how the sample is constructed. We also find the same basic pattern when we limit the sample to focus on specific types of countries-poor countries, rich countries, highinequality countries, low-inequality countries, Asian countries, European countries, and so on. In all cases, the results are remarkably robust. Given this evidence, we find it reasonable to conclude that lower-SES students are not any more sensitive to school composition than are higher-SES students.

That said, our findings must be interpreted with great care. One drawback of our study is that we cannot directly measure the true size of school composition effects - we only have measures of school composition and test scores at a single point in time, with no control over the process by which students end up in different schools. As a result, the differences in test scores 
between higher-SES and lower-SES schools are not entirely attributable to characteristics of the schools themselves; some of the differences undoubtedly reflect pre-existing student characteristics. This means that our models almost certainly overstate the true impact of school composition on test scores. We argue, though, that it does not entirely preclude our ability to draw conclusions based on this data. For the purpose of examining whether the relationship between test scores and school composition is strongest for lower-SES students, the key assumption is that whatever bias there is in our estimates, it is more or less the same in nature and degree for students of all socioeconomic levels. We argue that to the extent that the bias does differ between higher-SES and lower-SES students, it is likely higher for lower-SES students, and would thus bias our results in the opposite direction of what we find and report.

A second aspect of our study design that limits the scope of our conclusions is that the only outcome we examine is student learning as measured by standardized test scores. Longer term outcomes, such as high school graduation or college enrollment, might be affected by school composition differently—and perhaps more strongly—-than test scores. Test scores are still useful to examine - they are strongly correlated with other outcomes, and they are important in and of themselves, a reflection of the acquisition of knowledge needed to be a functional and well-informed citizen. But our finding is only that school composition does not matter more for lower-SES students in terms of their test scores; it might still matter more for their ability to translate those scores into longer-term success.

What are the implications of our findings for education policy? The policy recommendation that perhaps most commonly emerges from the literature on school composition effects is that the solution to educational inequality is the economic desegregation of schools, or the promotion of middle class schools. Given that we find school composition to matter more for 
higher-SES students, an extreme reading of our results might suggest that if the goal is to maximize overall achievement, higher-SES students should be segregated from lower-SES students in order to increase their scores by more than would be lost from the scores of lowerSES students. We strongly caution against such an interpretation, though, and we only raise it here so that we can directly refute it. Based on the evidence presented, the interpretation is unwarranted for three reasons. First, the interaction between school composition and individual SES is positive but small in magnitude; in most country-specific models, it is not even statistically significant. This, combined with the imprecision in our measurement of composition effects, probably means that while our results do suggest that composition effects are not larger for lower-SES students than for other students, there is not sufficient evidence to conclude the opposite. Second, in none of our models does the interaction effect appear to have a magnitude of more than about 10 points. This would imply that higher-SES students gain at most around ten points (or about one-tenth of a standard deviation) more than lower-SES students from attending the highest-SES schools. Such a small benefit would easily be outweighed by other benefits of middle class schools, such as promoting a sense of community and social solidarity, preventing the social exclusion of the most disadvantaged students, and teaching kids to interact with a diverse community. Third, our analysis is limited to test scores, and as discussed above, socioeconomic composition might have different effects on other types of outcomes.

In the end, we feel our results speak more directly to theoretical models of social reproduction and education than they do to specific policy discussions. Our findings suggest that the idea of schools being equalizers that provide disadvantaged students what their more advantaged peers get at home may be flawed, or at least incomplete. Whatever it is about school composition that affects student learning, it appears to affect all students more or less equally, at 
least within this age group. It might be that the skills taught in school at age 15-the population examined in this study — are not generally taught outside of formal schooling, even to higher SES students. Thus, what is provided by schools is equally critical for all students. 


\section{References}

Alexander, Karl L., Doris R. Entwisle, and Linda Steffel Olson. 2007. "Lasting Consequences of the Summer Learning Gap.” American Sociological Review 72:167-180.

American Educational Research Association. 2003. "Class Size: Counting Students Can Count." Research Points 1(2):1-4.

Burkam, David T., Douglas D. Ready, Valerie E. Lee, and Laura F. LoGerfo. 2004. "SocialClass Differences in Summer Learning Between Kindergarten and First Grade: Model Specification and Estimation." Sociology of Education 77:1-31.

Coleman, James S., Ernest Q. Campbell, Carol J. Hobson, James McPartland, Alexander M. Mood, Frederic D. Weinfield, and Robert L. York. 1966. Equality of Educational Opportunity. Washington, D. C.: National Center for Educational Statistics.

Cooper, Harris, Barbara Nye, Kelly Charlton, James Lindsay, and Scott Greathouse. 1996. "The Effects of Summer Vacation on Achievement Test Scores: A Narrative and MetaAnalytic Review." Review of Educational Research 66:227-68.

Dale, Stacy. And Alan B. Krueger. 2011. "Estimating the Return to College Selectivity over the Career Using Administrative Earnings Data." National Bureau of Economic Research Working Paper 17159.

Downey, Douglas B., Paul T. von Hippel, and Beckett A. Broh. 2004. "Are Schools the Great Equalizer? Cognitive Inequality During the Summer Months and the School Year." American Sociological Review 69:613-35.

Entwisle, Doris R. and Karl L. Alexander. 1992. "Summer Setback: Race, Poverty, School Composition, and Mathematics Achievement in the First Two Years of School." American Sociological Review 57:72-84.

Grissmer, David, Ann Flanagan, Jennifer Kawata, and Stephanie Williamson. 2000. Improving Student Achievement: What State NAEP Test Scores Tell Us. Santa Monica, CA: RAND.

Hanushek, Eric A., John F. Kain, and Steven G. Rivkin. 1998. "Teachers, Schools, and Academic Achievement.” NBER Working Paper 6691.

Heyns, Barbara. 1978. Summer Learning and the Effects of Schooling. New York: Academic. . 1987. "Schooling and Cognitive Development: Is There a Season for Learning?" Child Development 58:1151-60. 
Kahlenberg, Richard D. 2001. All Together Now: Creating Middle-Class Schools through Public School Choice. Brookings Institution Press.

Marks, Gary N. 2015. "Are School-SES effects Statistical Artefacts? Evidence from Longitudinal Population Data." Oxford Review of Education 41:122-144.

McConney, Andrew and Laura B. Perry. 2010. "Science and Mathematics Achievement in Australia: The Role of School Socioeconomic Composition in Educational Equity and Effectiveness." International Journal of Science and Mathematics Education 8:429-452.

Nye, Barbara A., Larry V. Hedges, and Spyros Konstantopoulos. 2000. "Do the Disadvantaged Benefit More from Small Classes? Evidence from the Tennessee Class Size Experiment." American Journal of Education 109:1-26.

Organisation for Economic Co-operation and Development. 2004. Learning for Tomorrow's World: First Results from PISA 2003. Paris: OECD Publishing. . 2016. PISA 2015 Results (Volume I): Excellence and Equity in Education. Paris: OECD Publishing.

Palardy, Gregory J. 2008. "Differential School Effects among Low, Middle, and High Social Class Composition Schools: A Multiple Group, Multilevel Latent Growth Curve Analysis." School Effectiveness and School Improvement 19:21-49.

Perry, Laura and Andrew McConney. 2010a. "School Socio-Economic Composition and Student Outcomes in Australia: Implications for Educational Policy." Australian Journal of Education 54:72-85.

. 2010b. "Does the SES of the School Matter? An Examination of Socioeconomic Status and Student Achievement Using PISA 2003." Teachers College Record 112: 1137-1162.

. 2013. "School Socioeconomic Status and Student Outcomes in Reading and Mathematics: A Comparison of Australia and Canada." Australian Journal of Education 57:124-140.

Rumberger, Russell W. and Gregory J. Palardy. 2005a. "Does Segregation Still Matter? The Impact of Student Composition on Academic Achievement in High School." Teachers College Record 107:1999-2045.

. 2005b. "Test Scores, Dropout Rates, and Transfer Rates as Alternative Measures of School Performance." American Education Research Journal 42:1-42. 
Sirin, Selcuk R. 2005. "Socioeconomic Status and Academic Achievement: A Meta-Analytic Review of Research." Review of Educational Research 75:417-453.

Summers, Anita A. and Barbara L. Wolfe. 1977. "Do Schools Make a Difference?” American Economic Review 67:639-652.

Van Ewijk, Reyn and Peter Sleegers. 2010. "The Effect of Peer Socioeconomic Status on Student Achievement: A Meta-Analysis.” Educational Research Review 5(2):134-150.

Wells, Ryan. 2010. "Children of Immigrants and Educational Expectations: The Roles of School Composition." Teachers College Record 112:1679-1704.

Willms, J. Douglas. 1986. "Social Class Segregation and Its Relationship to Pupils' Examination Results in Scotland." American Sociological Review 51:224-241. 
Table 1. Variable descriptions

N Mean SD Min Max Notes

$\underline{\text { Student-level variables }}$

Science score

Reading score

Math score

Socioeconomic status

School-level variables

Socioeconomic composition (original variable)

Socioeconomic composition

(standardized)

Teacher credentials

Science resources

Disruptive teacher behavior

Disruptive student behavior

Country-level variables

OECD member (dummy)

GDP per capita (USD)

Gini coefficient

Education expenditures (\% of GDP)

$\begin{array}{ccccc}498,493 & 464.8 & 101.7 & 58.7 & 888.4 \\ 498,493 & 461.4 & 104.0 & 0.0 & 882.1 \\ 498,493 & 453.8 & 104.1 & 0.0 & 870.5 \\ 498,493 & -0.67 & 1.26 & -7.26 & 4.18\end{array}$

4.18

PISA index of economic, social, and cultural status (ESCS)

\begin{tabular}{|c|c|c|c|c|c|}
\hline 17,637 & -0.31 & 0.80 & -4.85 & 1.60 & Average ESCS of sampled students \\
\hline 17,637 & -0.05 & 0.58 & -5.30 & 2.02 & $\begin{array}{l}\text { Average ESCS of sample students, } \\
\text { standardized within countries by } \\
\text { student-level mean and SD }\end{array}$ \\
\hline 10,894 & 0.29 & 0.33 & 0.00 & 1.00 & $\begin{array}{l}\text { Proportion of teachers with Master's } \\
\text { deree equivalent (or more) }\end{array}$ \\
\hline 10,894 & 4.39 & 2.25 & 0 & 8 & $\begin{array}{l}\text { Count of up to } 8 \text { specific science } \\
\text { resources available in school }\end{array}$ \\
\hline 10,894 & -0.08 & 1.09 & -2.12 & 4.26 & $\begin{array}{l}\text { Degree to which teacher behaviors } \\
\text { hinder student learning }\end{array}$ \\
\hline 10,894 & 0.00 & 1.11 & -2.39 & 3.89 & $\begin{array}{l}\text { Degree to which student behavior } \\
\text { hinders student learning }\end{array}$ \\
\hline
\end{tabular}

$50 \quad 0.66$

27,423

23,066

1,832

101,447 Gross domestic product per capita, 2015

$\begin{array}{llll}50 & 35.10 & 7.01 & 25.6\end{array}$

51.3

Gini coefficent for 2015 or most recently-available year

$50 \quad 21.10$

6.57

6.04 Federal education expenditures per student as a percentage of GDP per capita, for 2013 or closest year available 


\begin{tabular}{|c|c|c|}
\hline Sample & Sample sizes & Description \\
\hline 0 & $\begin{array}{l}\text { Countries }=69 \\
\text { Schools }=17,911 \\
\text { Students }=519,334\end{array}$ & Full PISA dataset \\
\hline 1 & $\begin{array}{l}\text { Countries }=68 \\
\text { Schools }=17,678 \\
\text { Students }=509,182\end{array}$ & $\begin{array}{l}\text { Drop countries and other geographic entities with insuficient information } \\
\text { to calculate individual SES or school composition }\end{array}$ \\
\hline 2 & $\begin{array}{l}\text { Countries }=68 \\
\text { Schools }=17,637 \\
\text { Students }=498,493\end{array}$ & Sample 1, minus students with missing data on individual ESCS variable \\
\hline 3 & $\begin{array}{l}\text { Countries }=50 \\
\text { Schools }=14,444 \\
\text { Students }=383,171\end{array}$ & Sample 2, minus countries with missing country-level variables \\
\hline 4 & $\begin{array}{l}\text { Countries }=47 \\
\text { Schools }=10,894 \\
\text { Students }=290,332\end{array}$ & Sample 3, minus schools with missing school-level variables \\
\hline
\end{tabular}


Table 3. Mean science score, by individual SES and school socioeconomic composition, for a single country (France)

\begin{tabular}{|c|c|c|c|c|c|c|c|}
\hline & \multirow[b]{2}{*}{$\begin{array}{l}\text { All school } \\
\text { quintiles }\end{array}$} & \multicolumn{5}{|c|}{ School socioeconomic composition } & \multirow[b]{2}{*}{$\begin{array}{l}\text { "Composition } \\
\text { Effect" }\end{array}$} \\
\hline & & $\begin{array}{l}\text { Bottom } \\
\text { quintile }\end{array}$ & $\begin{array}{l}\text { Second } \\
\text { quintile }\end{array}$ & $\begin{array}{l}\text { Middle } \\
\text { quintile }\end{array}$ & $\begin{array}{c}\text { Fourth } \\
\text { quintile }\end{array}$ & $\begin{array}{c}\text { Top } \\
\text { quintile }\end{array}$ & \\
\hline All SES quintiles & 498 & 400 & 470 & 518 & 547 & 567 & 167 \\
\hline \multicolumn{8}{|l|}{ Individual SES } \\
\hline$\overline{\text { Bottom quintile }}$ & 436 & 390 & 449 & 493 & 522 & 513 & 123 \\
\hline Second quintile & 470 & 405 & 468 & 507 & 525 & 527 & 122 \\
\hline Middle quintile & 492 & 400 & 465 & 518 & 534 & 547 & 147 \\
\hline Fourth quintile & 529 & 434 & 490 & 524 & 554 & 565 & 131 \\
\hline Top quintile & 563 & 415 & 511 & 543 & 572 & 584 & 169 \\
\hline
\end{tabular}

$\mathrm{N}=5,941$. A "composition effect" is the difference in average science scores bewteen students attending schools in the top quintile and those attending schools in the bottom quintile. Quintiles are defined within countries. School socioeconomic composition is the average SES of sampled students in the school. 
Table 4. Size of school socioeconomic composition effect ${ }^{1}$, by individual SES quintile

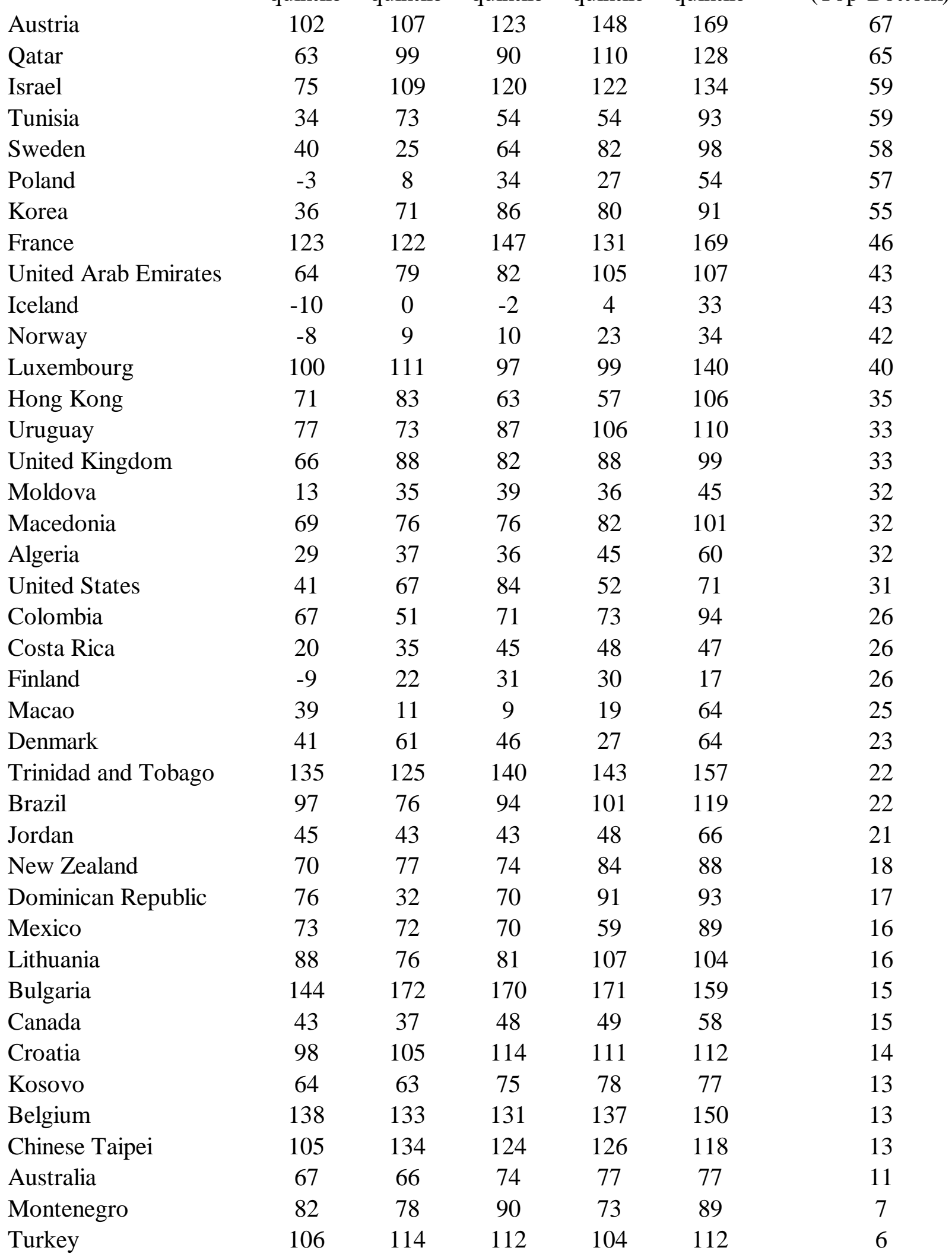

$\begin{array}{lccccc}\begin{array}{l}\text { Bottom } \\ \text { quintile }\end{array} & \begin{array}{c}\text { 2nd } \\ \text { quintile }\end{array} & \begin{array}{c}\text { Middle } \\ \text { quintile }\end{array} & \begin{array}{c}\text { 4th } \\ \text { quintile }\end{array} & \begin{array}{c}\text { Top } \\ \text { quintile }\end{array} & \begin{array}{c}\text { Difference }^{2} \\ \text { (Top-Bottom) }\end{array}\end{array}$

25

$4-33$

$\begin{array}{lllll}105 & 134 & 124 & 126 & 118\end{array}$ 
Table 4, continued.

\begin{tabular}{|c|c|c|c|c|c|c|}
\hline Portugal & 82 & 64 & 81 & 102 & 84 & 2 \\
\hline Netherlands & 161 & 145 & 146 & 153 & 163 & 2 \\
\hline Slovak Republic & 148 & 126 & 135 & 131 & 149 & 1 \\
\hline Vietnam & 91 & 58 & 59 & 57 & 92 & 1 \\
\hline Russia & 50 & 40 & 46 & 60 & 50 & 1 \\
\hline Greece & 76 & 113 & 89 & 91 & 77 & 1 \\
\hline Estonia & 41 & 35 & 55 & 37 & 41 & 0 \\
\hline Ireland & 41 & 35 & 37 & 37 & 40 & -1 \\
\hline Hungary & 155 & 135 & 158 & 176 & 148 & -7 \\
\hline Georgia & 74 & 60 & 75 & 67 & 66 & -8 \\
\hline Italy & 98 & 82 & 112 & 112 & 89 & -9 \\
\hline Malta & 142 & 127 & 137 & 134 & 133 & -9 \\
\hline Germany & 131 & 118 & 118 & 138 & 120 & -10 \\
\hline Japan & 125 & 119 & 111 & 119 & 113 & -12 \\
\hline Slovenia & 170 & 149 & 151 & 166 & 157 & -13 \\
\hline Latvia & 74 & 45 & 51 & 39 & 55 & -19 \\
\hline Romania & 116 & 95 & 97 & 99 & 93 & -23 \\
\hline Spain & 55 & 32 & 43 & 35 & 24 & -31 \\
\hline Singapore & 126 & 125 & 113 & 96 & 93 & -32 \\
\hline Switzerland & 125 & 87 & 113 & 104 & 92 & -33 \\
\hline Czech Republic & 176 & 142 & 137 & 149 & 117 & -58 \\
\hline Argentina $^{3}$ & $* * *$ & 95 & 71 & 79 & $* * *$ & \\
\hline Chile & $* * *$ & $* * *$ & 74 & 101 & 159 & \\
\hline China $^{4}$ & $* * *$ & 122 & 154 & 160 & 187 & \\
\hline Indonesia & $* * *$ & 62 & 76 & 77 & 114 & \\
\hline Lebanon & $* * *$ & 95 & 76 & 82 & 100 & \\
\hline Peru & $* * *$ & 68 & 90 & 97 & 86 & \\
\hline Thailand & $* * *$ & 84 & 71 & $* * *$ & $* * *$ & \\
\hline
\end{tabular}

${ }^{1}$ School socioeconomic composition is the average SES of sampled students within a school; quintiles are defined within countries. A "composition effect" is the difference in average science scores between students in top-quintile schools versus those in bottom-quintile schools.

${ }^{2}$ The final column shows the difference between the composition effect for top-quintile students and the composition effect for bottom-quintile students. Positive numbers indicate that effects are larger for higher-SES students; negative numbers mean they are larger for lower-SES students. ${ }^{3}$ Data for Argentina is for the city of Buenos Aires.

${ }^{4}$ Data for China is from four participating provinces: Beijing, Shanghai, Jiangsu, and Guangdong. ***Composition effects are not calculated for some countries/individual SES quntiles due to small sample sizes (i.e., fewer than 10 students) in the quintile attending schools in either the top or bottom quintile. 
Table 5. Hierarchical linear models predicting a student's score on the science literacy section of the PISA

\begin{tabular}{|c|c|c|c|c|c|c|c|c|c|c|}
\hline \multirow{3}{*}{$\begin{array}{l}\text { Sample }^{1} \text { : } \\
\text { Student SES quintile }\end{array}$} & \multicolumn{2}{|c|}{ Model 1} & \multicolumn{4}{|c|}{ Model 2} & \multirow{2}{*}{\multicolumn{2}{|c|}{$\begin{array}{l}\text { Model } 3 \\
\text { Sample } 4\end{array}$}} & \multirow{2}{*}{\multicolumn{2}{|c|}{$\begin{array}{l}\text { Model } 4 \\
\text { Sample } 4\end{array}$}} \\
\hline & \multicolumn{2}{|c|}{ Sample 2} & \multicolumn{2}{|c|}{ Sample 2} & \multicolumn{2}{|c|}{ Sample 4} & & & & \\
\hline & Coef. & SE & Coef. & SE & Coef. & SE & Coef. & SE & Coef. & SE \\
\hline 2nd quintile & 11.2 & $0.3 * * *$ & 13.2 & $0.4 * * *$ & 14.4 & $0.6 * * *$ & 14.4 & $0.6 * * *$ & 14.3 & $0.6 * * *$ \\
\hline Middle quintile & 17.9 & $0.4 * * *$ & 20.1 & $0.4 * * *$ & 21.6 & $0.6 * * *$ & 21.6 & $0.6 * * *$ & 21.5 & $0.6 * * *$ \\
\hline 4th quintile & 27.5 & $0.4 * * *$ & 29.5 & $0.4 * * *$ & 32.6 & $0.6 * * *$ & 32.6 & $0.6 * * *$ & 32.5 & $0.6 * * *$ \\
\hline Top quintile & 40.0 & $0.4 * * *$ & 41.7 & $0.5 * * *$ & 45.8 & $0.6 * * *$ & 45.8 & $0.6 * * *$ & 45.7 & $0.6 * * *$ \\
\hline School composition & 55.6 & $0.5 * * *$ & 49.1 & $0.8 * * *$ & 43.1 & $1.0 * * *$ & 43.1 & $1.0 * * *$ & 37.4 & $1.0 * * *$ \\
\hline School comp. x 2nd quint. & & & 5.5 & $0.9 * * *$ & 5.3 & $1.1 * * *$ & 5.3 & $1.1 * * *$ & 5.0 & $1.1 * * *$ \\
\hline School comp. x 3rd quint. & & & 9.9 & $0.9 * * *$ & 10.9 & $1.1 * * *$ & 10.9 & $1.1 * * *$ & 10.4 & $1.1 * * *$ \\
\hline School comp. $\mathrm{x}$ 4th quint. & & & 9.1 & $0.9 * * *$ & 9.3 & $1.2 * * *$ & 9.3 & $1.2 * * *$ & 8.6 & $1.2 * * *$ \\
\hline School comp. x Top quint. & & & 8.8 & $1.0 * * *$ & 9.6 & $1.2 * * *$ & 9.6 & $1.2 * * *$ & 8.8 & $1.2 * * *$ \\
\hline OECD & & & & & & & 47.6 & $10.0 * * *$ & 47.7 & $10.0 * * *$ \\
\hline GDP per capita & & & & & & & 9.0 & 4.7 & 9.1 & $4.7 *$ \\
\hline Gini coefficient & & & & & & & -7.4 & 4.0 & -7.3 & 3.9 \\
\hline Education spending & & & & & & & 10.0 & $4.1 *$ & 9.9 & $4.1 *$ \\
\hline Teacher credentials & & & & & & & & & 16.7 & $1.6 * * *$ \\
\hline Science resources & & & & & & & & & 2.1 & $0.2 * * *$ \\
\hline Poor student behavior & & & & & & & & & -7.1 & $0.4 * * *$ \\
\hline Poor teacher behavior & & & & & & & & & 3.5 & $0.4 * * *$ \\
\hline Constant & 446.5 & 6.0 & 444.0 & 6.0 & 439.2 & 6.7 & 409.8 & 7.5 & 409.5 & 7.4 \\
\hline Sample size & 498,49 & & 498,49 & & 290,33 & & 290,33 & & 290,33 & \\
\hline
\end{tabular}

$* * * \mathrm{p}<.001, * * \mathrm{p}<.01, * \mathrm{p}<.05$

${ }^{1}$ See Table 2 for sample descriptions. 
Table 6. Regression of SCIENCE scores on SES and school composition, comparing alternative coding strategies

$\mathrm{A}-\mathrm{B}-\mathrm{C}-\mathrm{D}-\mathrm{F}$

Student SES

Continuous

$15.1 * * * \quad 13.2 * * *$

$11.3 * * *$

2nd quintile

Middle quintile

4th quintile

Top quintile

$\begin{array}{lll}12.2 * * * & 10.5 * * * \\ 23.1 * * * & 14.4 * * * \\ 38.9 * * * & 22.6 * * * \\ 59.5 * * * & 34.5 * * *\end{array}$

$9.9 * * *$

$11.4 * * *$

$21.5 * * *$

$34.1 * * *$

School Socioeconomic Composition

Continuous

$55.9 * * *$

$85.8 * * *$

2nd quintile

$20.1 * * *$

Middle quintile

$29.5 * * *$

$41.7 * * *$

4th quintile

$49.1 * * *$

$20.0 * * *$

$34.0 * * *$

$52.7 * * *$

$76.0 * * *$

Nonpoor (dummy)

$53.7 * * *$

$45.2 * * *$

\section{Student SES-School Composition Interaction}

Continous x Continuous

Student (cont.) x School 2nd qu

Student (cont.) x School 3rd qu

Student (cont.) x School 4th qu

Student (cont.) x School 5th qu

Student 2nd qu x School (cont.)

Student 3rd qu x School (cont.)

Student 4th qu x School (cont.)

Student Top qu x School (cont.)

Student 2nd qu x School 2nd qu

Student 2nd qu x School 3rd qu

Student 2nd qu x School 4th qu

Student 2nd qu x School Top qu

Student 3rd qu x School 2nd qu

Student 3rd qu x School 3rd qu

Student 3rd qu x School 4th qu

Student 3rd qu x School Top qu

Student 4th qu x School 2nd qu

Student 4th qu x School 3rd qu

Student 4th qu x School 4th qu

Student 4th qu x School Top qu

Student Top qu x School 2nd qu

Student Top qu x School 3rd qu

Student Top qu x School 4th qu

Student Top qu x School Top qu

Student cont. x Nonpoor school

Student 2nd qu x Nonpoor

Student 3rd qu x Nonpoor

Student 4th qu $x$ Nonpoor

Student Top qu x Nonpoor

Constant

468.0

444.0

498,493

498,493

Sample size
$5.5 * * *$

$9.9 * * *$

$9.1 * * *$

$8.8 * * *$

$2.6 * * *$

$4.1 * * *$

$4.9 * * *$

$5.0 * * *$

427.2

407.8

420.9

498,493

$3.0 * *$

$9.8 * * *$

$10.5 * * *$

$11.9 * * *$

498,493

403.0

498,493 
Table 7. Regression of READING scores on SES and school composition, comparing alternative coding strategies

A

B

E

$\mathrm{F}$

Student SES

Continuous

$14.0 * * *$

$11.8 * * *$

$10.9 * * *$

2nd quintile

Middle quintile

4th quintile

Top quintile

$13.8 * * *$

$20.2 * * *$

$28.5 * * *$

$39.4 * * *$

$13.8 * * *$

$22.4 * * *$

$32.8 * * *$

$53.3 * * *$

Continuous

$59.9 * * *$

$25.8 * * *$

$42.8 * * *$

$64.5 * * *$

$92.2 * * *$

Nonpoor (dummy)

\section{Student SES-School Composition Interaction}

Continous x Continuous

$2.2 * * *$

Student (cont.) x School 2nd qu

Student (cont.) x School 3rd qu

Student (cont.) x School 4th qu

Student (cont.) x School 5th qu

Student 2nd qu x School (cont.)

Student 3rd qu x School (cont.)

Student 4th qu x School (cont.)

Student Top qu x School (cont.)

Student 2nd qu x School 2nd qu

Student 2nd qu x School 3rd qu

Student 2nd qu x School 4th qu

Student 2nd qu x School Top qu

Student 3rd qu x School 2nd qu

Student 3rd qu x School 3rd qu

Student 3rd qu x School 4th qu

Student 3rd qu x School Top qu

Student 4th qu x School 2nd qu

Student 4th qu x School 3rd qu

Student 4th qu x School 4th qu

Student 4th qu x School Top qu

Student Top qu x School 2nd qu

Student Top qu x School 3rd qu

Student Top qu x School 4th qu

Student Top qu x School Top qu

Student cont. x Nonpoor school

Student 2nd qu x Nonpoor

Student 3rd qu x Nonpoor

Student 4th qu $x$ Nonpoor

Student Top qu x Nonpoor

Constant

463.1

419.4

498,493

498,493

$$
\begin{aligned}
& 2.2 * * * \\
& 3.2 * * * \\
& 3.7 * * * \\
& 3.0 * * *
\end{aligned}
$$

$5.8 * * *$

$10.5 * * *$

$9.1 * * *$

$8.5 * * *$
Sample size

439.5

399.5

498,493
$22.8 * * *$

$38.5 * * *$

$57.9 * * *$

$82.9 * * *$

$58.6 * * *$

$50.2 * * *$
$9.7 * * *$

$10.3 * * *$

$20.8 * * *$

$31.8 * * *$

411.4

394.1

498,493

498,493 
Table 8. Regression of MATH scores on SES and school composition, comparing alternative coding strategies

\begin{tabular}{|c|c|c|c|c|}
\hline & A & $\mathrm{B}$ & $\mathrm{C}$ & $\mathrm{D}$ \\
\hline \multicolumn{5}{|l|}{ Student SES } \\
\hline Continuous & $15.1 * * *$ & $12.5 * * *$ & & \\
\hline 2nd quintile & & & $12.7 * * *$ & 10.2 \\
\hline Middle quintile & & & $19.6 * * *$ & 15.0 \\
\hline 4th quintile & & & $28.8 * * *$ & 22.9 \\
\hline Top quintile & & & $41.3 * * *$ & 34.9 \\
\hline \multicolumn{5}{|c|}{ School Socioeconomic Composition } \\
\hline Continuous & $53.6 * * *$ & & $47.4 * * *$ & \\
\hline 2nd quintile & & $21.7 * * *$ & & 19.6 \\
\hline Middle quintile & & $36.5 * * *$ & & 32.1 \\
\hline 4th quintile & & $56.1 * * *$ & & 50.1 \\
\hline Top quintile & & $82.0 * * *$ & & 74.1 \\
\hline
\end{tabular}

Nonpoor (dummy)

\section{Student SES-School Composition Interaction}

Continous x Continuous

Student (cont.) x School 2nd qu

Student (cont.) x School 3rd qu

Student (cont.) x School 4th qu

Student (cont.) x School 5th qu

Student 2nd qu x School (cont.)

Student 3rd qu x School (cont.)

Student 4th qu x School (cont.)

Student Top qu x School (cont.)

Student 2nd qu x School 2nd qu

Student 2nd qu x School 3rd qu

Student 2nd qu x School 4th qu

Student 2nd qu x School Top qu

Student 3rd qu x School 2nd qu

Student 3rd qu x School 3rd qu

Student 3rd qu x School 4th qu

Student 3rd qu x School Top qu

Student 4th qu $x$ School 2nd qu

Student 4th qu x School 3rd qu

Student 4th qu x School 4th qu

Student 4th qu x School Top qu

Student Top qu x School 2nd qu

Student Top qu x School 3rd qu

Student Top qu x School 4th qu

Student Top qu x School Top qu

Student cont. x Nonpoor school

Student 2nd qu x Nonpoor

Student 3rd qu x Nonpoor

Student 4th qu x Nonpoor

Student Top qu x Nonpoor

Constant

Sample size

498,493
$3.3 * * *$

$$
\begin{aligned}
& 2.1 * * * \\
& 3.9 * * * \\
& 4.5 * * * \\
& 4.6 * * *
\end{aligned}
$$

$5.2 * * *$

$8.8 * * *$

$8.4 * * *$

$8.4 * * *$

1.0

$2.1 *$

$3.7 * *$

$4.9 * *$

$2.2 *$

$4.9 * * *$

$6.7 * * *$

$8.7 * * *$

$4.1 * * *$

$5.8 * * *$

$9.3 * * *$

$10.4 * * *$

$3.4 * *$

$7.6 * * *$

$8.6 * * *$

$13.0 * * *$
$51.3 * * *$

$43.6 * * *$

$9.5 * * *$

$12.1 * * *$

$21.3 * * *$

$33.9 * * *$

$11.4 * * *$

$43.6 * *$

F

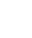


Table 9. Countries with positive/negative interactions between school socioeconomic composition and individual SES in country-specific, two-level hierarchical linear models

\begin{tabular}{|c|c|c|c|c|c|}
\hline Negative interaction & \multicolumn{3}{|c|}{ Insignificant interaction $(\mathrm{p}>.05)$} & \multicolumn{2}{|c|}{ Positive interaction } \\
\hline $\begin{array}{l}\text { Japan } \\
\text { Latvia } \\
\text { Spain }\end{array}$ & $\begin{array}{l}\text { Negative direction } \\
\text { Argentina }{ }^{1} \\
\text { Czech Republic } \\
\text { Estonia } \\
\text { France } \\
\text { Greece } \\
\text { Ireland } \\
\text { Jordan } \\
\text { New Zealand } \\
\text { Portugal } \\
\text { Russia } \\
\text { Singapore } \\
\text { Switzerland } \\
\text { Vietnam }\end{array}$ & $\begin{array}{l}\text { Positive directic } \\
\text { Algeria } \\
\text { Belgium } \\
\text { Bulgaria } \\
\text { Chile } \\
\text { China }^{2} \\
\text { Chinese Taipei } \\
\text { Costa Rica } \\
\text { Croatia } \\
\text { Finland } \\
\text { Georgia } \\
\text { Germany } \\
\text { Hong Kong } \\
\text { Hungary } \\
\text { Italy }\end{array}$ & $\begin{array}{l}\text { Korea } \\
\text { Lebanon } \\
\text { Lithuania } \\
\text { Luxembourg } \\
\text { Macao } \\
\text { Macedonia } \\
\text { Malta } \\
\text { Montenegro } \\
\text { Netherlands } \\
\text { Romania } \\
\text { Slovenia } \\
\text { Trinidad \& Tob. } \\
\text { Turkey } \\
\text { United Kingdom }\end{array}$ & $\begin{array}{l}\text { Australia } \\
\text { Austria } \\
\text { Brazil } \\
\text { Canada } \\
\text { Colombia } \\
\text { Denmark } \\
\text { Dominican Rep. } \\
\text { Iceland } \\
\text { Indonesia } \\
\text { Israel } \\
\text { Kosovo } \\
\text { Mexico }\end{array}$ & $\begin{array}{l}\text { Moldova } \\
\text { Norway } \\
\text { Peru } \\
\text { Poland } \\
\text { Qatar } \\
\text { Slovak Republic } \\
\text { Sweden } \\
\text { Thailand } \\
\text { Tunisia } \\
\text { United Arab Em. } \\
\text { United States } \\
\text { Uruguay }\end{array}$ \\
\hline
\end{tabular}

${ }^{1}$ Data for Argentina is from the city of Buenos Aires.

${ }^{2}$ Data for China is from four participating provinces: Beijing, Shanghai, Jiangsu, and Guangdong. 
Individual SES

2nd quintile

3rd quintile

4th quintile

Top quintile

School composition

Interaction

School comp. x 2nd q

School comp. $x$ 3rd qu

School comp. $x$ th qu

School comp. $x$ Top qu

Sample size

Individual SES

2nd quintile

3rd quintile

4th quintile

Top quintile

School composition

Interaction

School comp. x 2nd q

School comp. $x$ 3rd qu

School comp. $x$ 4th qu

School comp. $x$ Top qu

Sample size

Individual SES

2nd quintile

3rd quintile

4th quintile

Top quintile

School composition

Interaction

School comp. x 2nd q

School comp. $x$ 3rd qu

School comp. $x$ th qu

School comp. $x$ Top qu

Sample size

\section{OECD}

$15.90 .6^{* * *}$

$24.10 .6 * * *$

$36.60 .6 * * *$

$50.60 .7 * * *$

$51.91 .0 * * *$

$4.8 \quad 1.2 * * *$

$9.71 .2 * * *$

$7.11 .3 * * *$

$5.61 .3 * * *$

274,911

Low inequality

$15.0 \quad 0.7 * * *$

$21.8 \quad 0.7 * * *$

$32.7 \quad 0.7 * * *$

$45.0 \quad 0.8 * * *$

$57.51 .2 * * *$

$6.11 .4 * * *$

$9.51 .5 * * *$

$9.61 .5 * * *$

$9.61 .6 * * *$

194,351

\section{High spending}

$15.8 \quad 0.7 * * *$

$23.90 .7 * * *$

$36.20 .7 * * *$

$52.0 \quad 0.8 * * *$

$54.3 \quad 1.2 * * *$

$4.51 .4 * * *$

$7.81 .4 * * *$

$5.8 \quad 1.4 * * *$

$2.81 .5 *$

211,565

\section{Non-OECD}

$\begin{array}{rl}9.1 & 0.6 * * * \\ 14.3 & 0.6 * * * \\ 19.6 & 0.6 * * * \\ 29.3 & 0.7 * * *\end{array}$

$47.21 .2 * * *$

$5.0 \quad 1.3 * * *$

$8.31 .3 * * *$

$10.91 .4 * * *$

223,582

\section{High inequality}

$12.0 \quad 0.6 * * *$

$18.50 .6^{* * *}$

$27.10 .6 * * *$

$40.7 \quad 0.7 * * *$

$41.71 .04 * * *$

$4.0 \quad 1.2 * * *$

$10.11 .2 * * *$

$9.31 .2 * * *$

$8.41 .3 * * *$

242,410

\section{Low spending}

$12.5 \quad 0.7 * * *$

$18.5 \quad 0.7 * * *$

$26.50 .7 * * *$

$36.30 .8 * * *$

$42.7 \quad 1.1 * * *$

$5.71 .3 * * *$

$11.91 .3 * * *$

$11.21 .4 * * *$

$13.51 .4 * * *$
$9.61 .3 * * *$

High GDP

$\begin{array}{ll}15.3 & 0.6 * * * \\ 24.5 & 0.6 * * * \\ 37.1 & 0.6 * * * \\ 49.3 & 0.7 * * * \\ & \\ 54.0 & 1.1 * * *\end{array}$

Less segregated

$13.6 \quad 0.7^{* * *}$

$22.40 .6 * * *$

$33.4 \quad 0.7 * * *$

$43.8 \quad 0.7 * * *$

$52.41 .3^{* * *}$

$10.11 .6 * * *$

223,845

Europe

$14.6 \quad 0.6 * * *$

$21.80 .6 * * *$

$33.20 .6 * * *$

$48.1 \quad 0.7 * * *$

$54.6 \quad 1.1 * * *$

207,268
$5.21 .3 * * *$

$9.21 .3 * * *$

$7.51 .3 * * *$

$7.8 \quad 1.4 * * *$

273,204

$5.4 \quad 1.4 * * *$

$7.8 \quad 1.5 * * *$

$8.1 \quad 1.5 * * *$

$3.81 .3 * *$

$8.0 \quad 1.3 * * *$

$6.51 .3 * * *$

$3.7 \quad 1.4 * *$

\section{Low GDP}

$\begin{array}{rr}9.2 & 0.6 * * * \\ 13.0 & 0.6 * * * \\ 18.4 & 0.6 * * * \\ 29.5 & 0.7 * * * \\ & \\ 46.5 & 1.1 * * *\end{array}$

$3.0 \quad 1.2 *$

$8.11 .2 * * *$

$8.61 .2 * * *$

$9.21 .3 * * *$

217,602

More segregated

$12.4 \quad 0.6^{* * *}$

$17.7 \quad 0.6 * * *$

$25.8 \quad 0.6 * * *$

$39.4 \quad 0.7 * * *$

$48.3 \quad 1.0 * * *$

$4.7 \quad 1.1 * * *$

$10.21 .1 * * *$

$9.31 .1 * * *$

$7.7 \quad 1.2 * * *$

274,648

Asia

$10.91 .2 * * *$

$14.11 .2 * * *$

$18.6 \quad 1.2 * * *$

$30.71 .3 * * *$

$55.22 .4 * * *$

256,702
$7.5 \quad 2.5 * *$

$6.7 \quad 2.5 * *$

$6.72 .5 * *$

$6.22 .6 * *$

65,810 
100

0 School

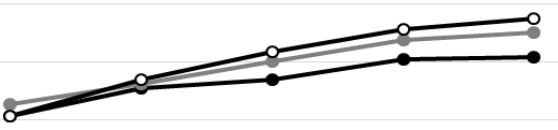

700

600

500

400

300

200

100 School Q1 Q2

\section{Mexico}
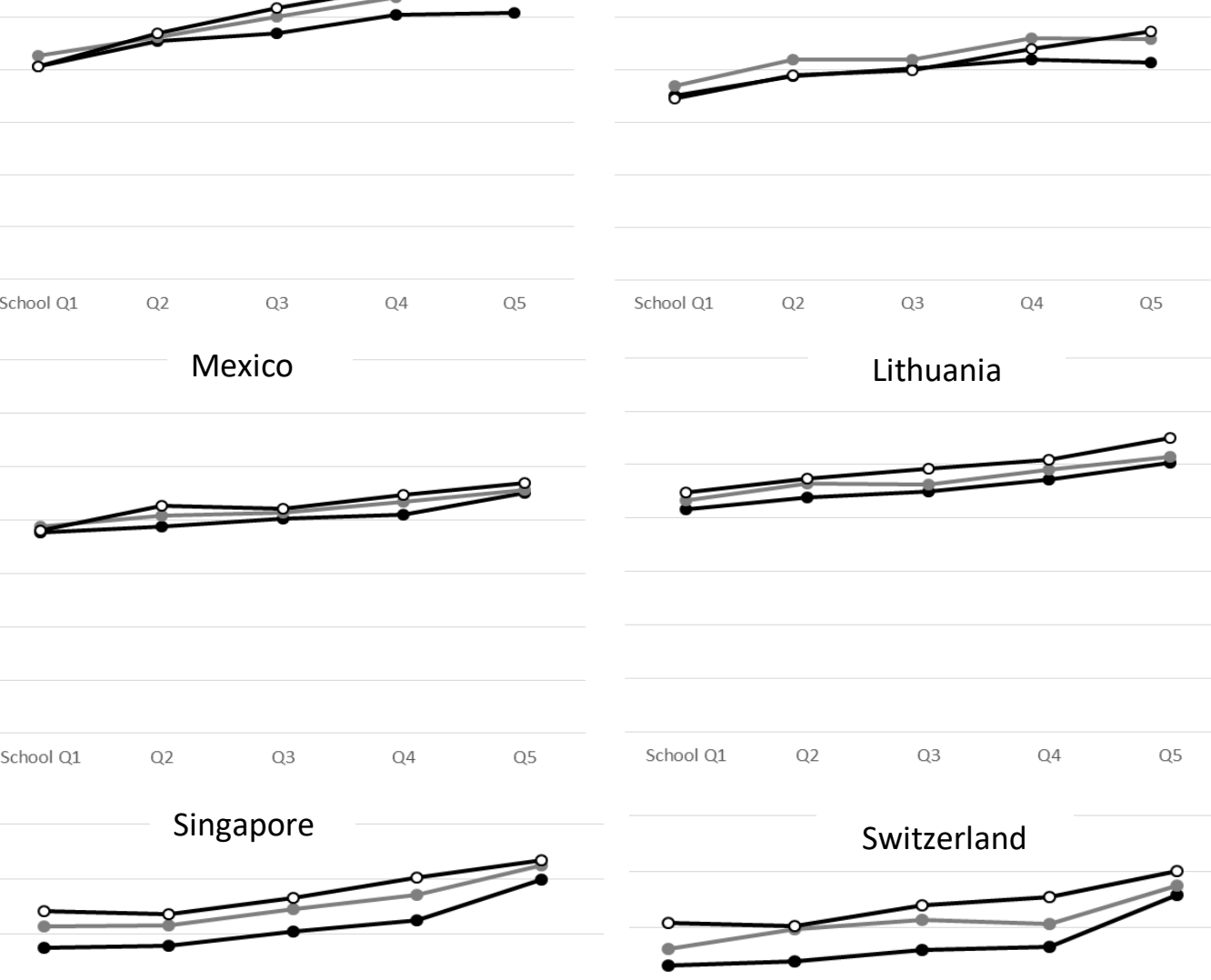

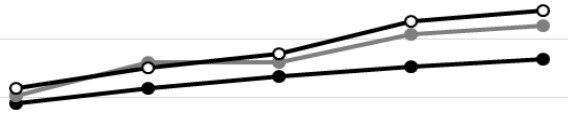

School Q1

Q2
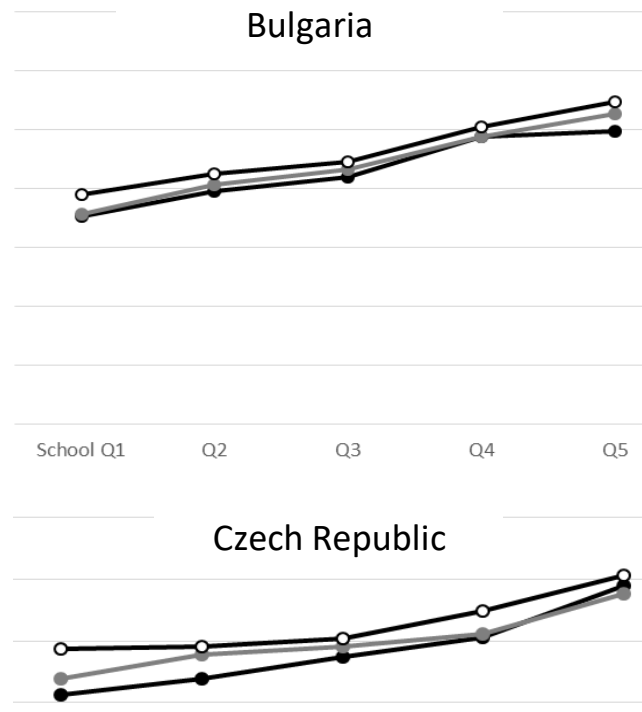

200

100
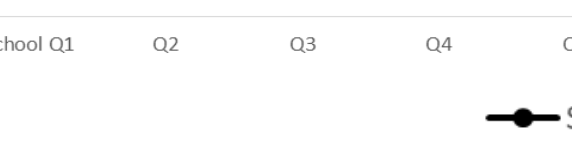

;chool Q1

Q2

Q3

Q4 Q5

School Q1

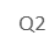

Q3

Q4

Figure 1. Mean science score, by school socioeconomic composition and student SES, for selected countries

Note: Graphs are shown for the three countries at the top of the list in Table 4, the three countries at the bottom of the list, and the three countries in the middle. 


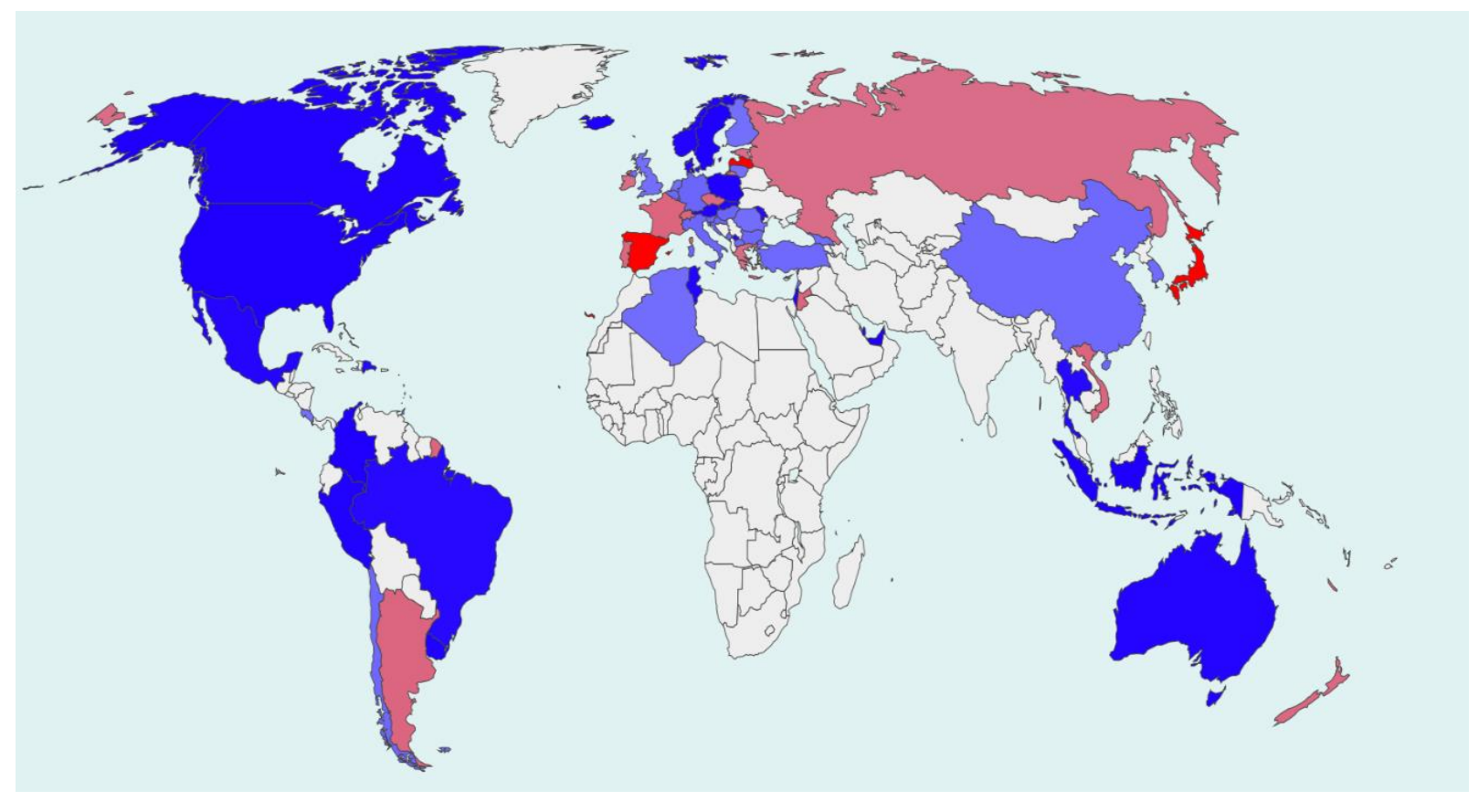

Figure 2. Countries with positive/negative interactions between individual SES and peer SES

Dark blue (red) shading indicates a statistically signficant positive (negative) interaction term in a two-level, country-specific HLM of student science score on individual SES and school socioeconomic composition. Light shading indicates an insignificant interaction term. Countries shaded gray had insufficient information to be included in the analysis. Map was drawn using www.paintmaps.com. 